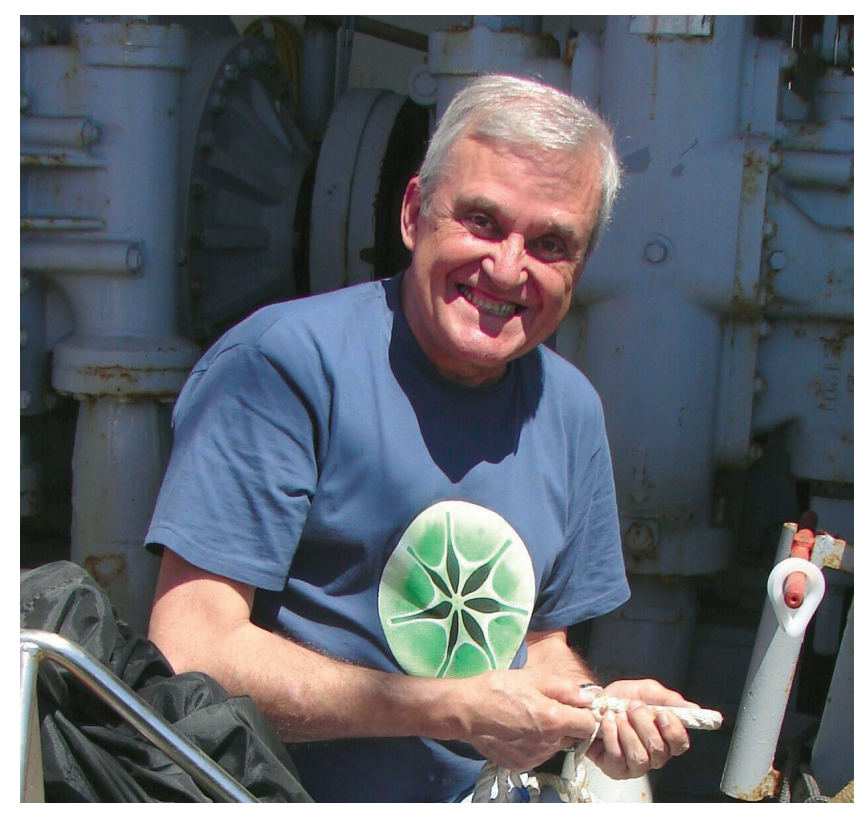

\title{
Agustí Julià i Brugués (1940-2009)
}

Avui sembla tan normal treballar al mar amb instruments electrònics que es fa difícil pensar com podíem treure informació de l'oceà sense fer-ne ús. No fa tants anys, però, hauria estat força estrany trobar cap aparell que funcionés amb piles o bateries en l'equipatge d'un oceanògraf. Quan l'Agustí va començar la seva carrera en el món de l'oceanografia, a l'Instituto de Investigaciones Pesqueras (actualment Institut de Ciències del Mar) als anys seixanta, parlar d'electrònica era parlar de telecomunicacions, ràdio i derivats. En un vaixell, tota l'electrònica estava al pont: la ràdio, el radar o el sónar eren els únics instruments on s'hi podien trobar resistències, díodes o transistors. Quin futur podia tenir un especialista en electrònica i telecomunicacions en un món dominat per termòmetres de mercuri, ampolles Nansen, xarxes de plàncton i microscopis, i en uns laboratoris d'anàlisi química plens de material de vidre i reactius de tota mena?

En Ramon Margalef, director de l'Institut quan l'Agustí va entrar-hi, va proposar-li que construís un enginy per comptar plàncton (Julià, 1969). Era un primer pas en la incorporació de l'electrònica a l'observació de l'oceà. Més endavant, amb l'arribada
d'Antoni Ballester a l'Institut, després d'una primera experiència amb AutoAnalitzadors en col-laboració amb l'Institut Royal de Brussel-les, l'Agustí va començar a treballar de ple en instrumentació oceanogràfica. Va ser l'època en què els oceanògrafs del nostre país començaven a participar en campanyes internacionals i a descobrir les possibilitats que donaven els nous instruments de mesura electrònics. Aquí, a l'Institut, l'Agustí va col-laborar decisivament en posar a punt l'anàlisi continu de paràmetres físics i químics de l'aigua de mar superficial (Ballester et al., 1972), que més tard es va generalitzar per tot el món oceanogràfic. També va participar en el desenvolupament, potser massa precoç, del Divergent, un dels primers aparells mostrejadors ondulants, gairebé vint anys abans dels actuals Sea-soar o altres sofisticats aparells arrossegats. Tot això just abans de l'entrada en servei del primer gran vaixell oceanogràfic espanyol, el Cornide de Saavedra, l'any 1971.

Als anys 70, amb l'impuls a la oceanografia que disposar del Cornide va permetre, la necessitat de nous instruments i l'explosió de l'electrònica van fer necessària la creació a l'Institut d'un equip de treball 
dedicat a la instrumentació. Format per l'Agustí, en Pep Martínez i en Joan Comas, el grup va desenvolupar prototipus i posar a prova tota mena de nous instruments, al llarg de més de 15 anys. Fins mitjans dels anys 80 va passar per llurs mans pràcticament tot allò de l'Institut que portés algun diode. Era el moment en què la instrumentació electrònica ja havia envaït tot l'espai dels laboratoris i de l'entorn de l'adquisició i procés de dades: correntímetres, batisondes, fluorímetres, etc. Tothom els feia servir. Va ser una època difícil i de molta feina, on l'Agustí era a tot arreu, intentant no desatendre ningú ni cap problema, i donant suport a molts dels mostrejos oceanogràfics que es feien. Fins i tot treia temps, no se sap d'on, per interessar-se, formar-se i experimentar amb noves tecnologies, com la utilització de satèl-lits per observar l'oceà. Va ser llavors, a finals de l'any 1986, quan l'Agustí va formar part de l'equip pioner en la recerca antàrtica al nostre país. Era un petit grup de quatre persones (A. Ballester, J. Castellví, A. Julià i J. Rovira) que, invitats per l'Acadèmia de Ciències de Polònia, va participar en la campanya antàrtica que va fixar la posició de la Base Antàrtica Espanyola a l'Illa Livingstone, obrint la porta a la candidatura espanyola com a membre consultiu del Tractat Antàrtic. Mesos després, aquest fet va portar l'Agustí, republicà convençut, a ser, curiosament, un dels pocs companys de l'Institut en rebre el reconeixement personal del Rei.

L'impuls que aquests aconteixements van representar per l'oceanografia al nostre país va ser extraordinari. Des del punt de vista de capacitat instrumental a l'Institut, va representar un salt de gairebé un ordre de magnitud i va comportar la creació d'una Unitat de Tecnologia Marina dedicada a atendre les necessitats instrumentals dels vaixells oceanogràfics i la Base Antàrtica. L'Agustí però, va continuar la seva activitat d'instrumentació pel dia a dia: correntímetres, anclatges, boies..., amb la incorporació de la Maribel Lloret a l'equip. Aquesta dedicació amb tot l'entusiasme i sense cap símptoma de defalliment va seguir molt més enllà de l'edat oficial de jubilació, fins caure malalt a mitjans del 2008 , just quan s'estava preparant amb tota la il-lusió per una nova campanya antàrtica, a la que malauradament ja no va poder anar.

El profund coneixement del mar, del comportament dels instruments en el medi marí i, molt especialment, la seva bona disposició en col-laborar amb tothom, va portar l'Agustí a treballar amb equips de moltes institucions tant del país com de fora, des de pràcticament l'inici de la seva vida professional. Les col-laboracions van ser especialment estretes amb el Laboratori d'Enginyeria Marítima de la UPC, però no van faltar amb pràcticament totes les institucions que treballaven en el món de l'oceanografia a Espanya: altres centres del CSIC, l'IEO, Puertos del Estado i moltes universitats. També va col-laborar amb centres del CNRS, l'IFREMER i universitats franceses, el CNR italià, equips d'universitats nordamericanes, etc.

La desaparició de l'Agustí ha deixat un buit important per als centenars de persones de tot arreu que en un moment o un altre havíem compartit hores de feina i de lleure amb ell, tant a terra com al mar. Estant al seu costat era pràcticament impossible caure en el desànim. Per molt adverses que fossin les condicions $-\mathrm{i}$ sovint ho eren!- amb ell tot semblava factible i molt més fàcil. "Cap problema!" solia diri, a continuació, "mans a l'obra" amb un somriure. El seu optimisme era tal que, poc abans de deixarnos, encara ens va fer creure que aviat tornaria a la feina. Malauradament no va ser així i l'hem perdut amb gran tristesa.

\section{REFERÈNCIES}

Ballester, A., A. Cruzado, A. Julià, M. Manríquez, J. Salat. - 1972. Análisis automático y continuo de las características físicas, químicas y biológicas del mar. Publ. Téc. Patronato Juan de la Cierva C.S.I.C., 1: 1-68.

Julià, A. - 1969. Contador óptico de partículas en suspensión de tamaño mediano y grande (micro y meso-plancton). Inv. Pesq., 33(1): 201-211.

JORDI SALAT Institut de Ciències del Mar (CMIMA-CSIC) 


\section{Agustí Julià i Brugués (1940-2009)}

Hoy en día es tan habitual trabajar en el mar con instrumentos electrónicos que resulta difícil pensar como conseguíamos sacar información del océano sin utilizarlos. No hace tanto, sin embargo, hubiera sido raro encontrar algún aparato que funcionara con pilas o baterías en el equipaje de un oceanógrafo. Cuando Agustí empezó su carrera en el mundo de la oceanografía, en el Instituto de Investigaciones Pesqueras (actualmente Instituto de Ciencias del Mar) en los años sesenta, hablar de electrónica era hablar de telecomunicaciones, radio y derivados. En un barco, toda la electrónica se encontraba en el puente: la radio, el radar o el sónar eran los únicos instrumentos que tenían resistencias, diodos o transistores. ¿Qué futuro podía esperar un especialista en electrónica y telecomunicaciones en un mundo dominado por termómetros de mercurio, botellas Nansen, redes de plancton y microscopios, y en unos laboratorios de análisis químico llenos de material de vidrio y reactivos de todo tipo?

Ramon Margalef, director del Instituto cuando Agustí empezó su carrera profesional, le propuso que construyera un instrumento para contar plancton (Julià, 1969). Se trató de un primer paso en el proceso de incorporación de la electrónica a la observación del océano. Más adelante, con la llegada de Antoni Ballester al Instituto, después de una primera experiencia con AutoAnalizadores en colaboración con el Institut Royal de Bruselas, Agustí empezó a trabajar de lleno en instrumentación oceanográfica. Era la época en que los oceanógrafos de nuestro país empezaban a participar en campañas internacionales y a descubrir las posibilidades que daban los nuevos instrumentos de medida electrónicos. Aquí, en el Instituto, Agustí colaboró decisivamente para poner a punto el análisis continuo de parámetros físicos y químicos del agua de mar superficial (Ballester et al., 1972), que más tarde se generalizó en el entorno oceanográfico internacional. También participó en el desarrollo, quizás demasiado precoz, del Divergente, uno de los primeros aparatos muestreadores ondulantes, casi veinte años antes de los actuales Sea-soar u otros sofisticados aparatos que se llevan remolcados. Todo ello justo antes de que entrara en servicio el primer gran buque oceanográfico español, el Cornide de Saavedra, el año 1971.

En los años 70, con el impulso a la oceanografía que representó poder disponer del Cornide, la necesidad de nuevos instrumentos y la explosión de la electrónica hicieron necesaria la creación de un equipo de trabajo, formado por Agustí, Pep Martínez y Joan Comas, dedicado a instrumentación en el seno del Instituto. A lo largo de más de 15 años este grupo, que lideraba Agustí, desarrolló muchos prototipos y puso a prueba todo tipo de nuevos instrumentos. Hasta mediados de los años 80, pasó por sus manos prácticamente cualquier cosa del Instituto que llevara algún diodo. Era el momento en que la instrumentación electrónica ya había invadido todo el espacio de los laboratorios y del entorno de adquisición y proceso de datos: correntímetros, batisondas, fluorímetros, etc. Todo el mundo los utilizaba. Resultó ser una época difícil y de mucho trabajo, durante la cual Agustí estaba en todas partes, intentando no desatender a nadie ni ningún problema, y dando apoyo a muchos de los muestreos oceanográficos que se llevaban a cabo. Incluso conseguía sacar tiempo, no se sabe bien de dónde, para interesarse, formarse y experimentar con nuevas tecnologías, tales como el uso de satélites en la observación del océano. Fue entonces, a finales del año 1986, cuando Agustí formó parte del equipo pionero en la investigación antártica en nuestro país. Se trataba de un pequeño grupo de cuatro personas (A. Ballester, J. Castellví, A. Julià y J. Rovira) que, invitados por la Academia de Ciencias de Polonia, participó en la campaña antártica que fijó la posición de la Base Antártica Española en la Isla Livingstone, abriendo la puerta a la candidatura española como miembro consultivo del Tratado Antártico. Meses después, este hecho llevó a Agustí, de ideas republicanas, a ser, curiosamente, uno de los pocos compañeros del Instituto que ha recibido el reconocimiento personal del Rey.

El impulso que estos acontecimientos representaron para la oceanografía en nuestro país fue extraordinario. Desde el punto de vista de capacidad instrumental en el Instituto, supuso un salto de casi un orden de magnitud y comportó la creación de una Unidad de Tecnología Marina dedicada a atender las necesidades instrumentales de los barcos oceanográficos y la Base Antártica. Agustí sin embargo, continuó su actividad en instrumentación del día a día: correntímetros, anclajes, boyas..., con la incorporación de Maribel Lloret en el equipo. Esta dedicación con todo su entusiasmo y sin nin- 
gún síntoma de desfallecimiento siguió mucho más allá de la edad oficial de jubilación, hasta caer enfermo a mediados de 2008, justo cuando se estaba preparando con toda la ilusión para participar en una nueva campaña antártica, a la que desgraciadamente ya no pudo ir.

El profundo conocimiento de la mar, del comportamiento de los instrumentos en el medio marino $\mathrm{y}$, muy especialmente, su buena disposición para colaborar con todos, llevó a Agustí a trabajar con colegas de muchas instituciones tanto del país como de fuera de él, desde prácticamente el inicio de su vida profesional. Las colaboraciones se extendieron a prácticamente todas las instituciones que trabajaban en el mundo de la oceanografía en España: otros centros del CSIC, el IEO, Puertos del Estado y muchas universidades, especialmente el Laboratorio de Ingeniería Marítima de la UPC. También colaboró con centros del CNRS, el IFREMER y universidades francesas, el CNR italiano, equipos de universidades norteamericanas, etc.

La desaparición de Agustí ha dejado un vacío importante para los cientos de personas que en un momento u otro habíamos compartido horas de trabajo y de ocio con él, tanto en tierra como en el mar. Estando en su lado era prácticamente imposible caer en el desánimo. Por muy adversas que fueran las condiciones -iy a menudo lo eran!- con él todo parecía factible y mucho más fácil. "¡Ningún problema!", solía decir, y, a continuación, "manos a la obra" con una sonrisa. Su optimismo era tal que, poco antes de dejarnos, todavía nos hizo creer que pronto volvería al trabajo. Desgraciadamente no fue así y su pérdida nos ha causado una gran tristeza.

\section{REFERENCIAS}

Ballester, A., A. Cruzado, A. Julià, M. Manríquez, J. Salat. - 1972. Análisis automático y continuo de las características físicas, químicas y biológicas del mar. Publ. Téc. Patronato Juan de la Cierva C.S.I.C., 1: 1-68.

Julià, A. - 1969. Contador óptico de partículas en suspensión de tamaño mediano y grande (micro y meso-plancton). Inv. Pesq., 33(1): 201-211.

\section{JORDI SALAT Institut de Ciències del Mar (CMIMA-CSIC)}

\section{Agustí Julià i Brugués (1940-2009)}

Working at sea with electronic instruments seems so normal today that it is hard to imagine how we were able to obtain information from the ocean without them. Not so long ago, however, it would have been surprising to find a battery-operated device among an oceanographer's equipment. In the 1960s, when Agustí started his career in the world of oceanography at the Fisheries Research Institute (now the Institute of Marine Science), electronics was only associated with telecommunications, radio and their related technologies. On a boat, all the electronics was on the bridge: radio, radar and sonar units were the only instruments containing resistors, diodes and transistors. In an oceanographic world dominated by mercury thermometers, Nansen bottles, plankton nets and microscopes, and in chemical analysis laboratories full of glass objects and all kinds of reagents, what could be the future of a specialist in electronics and telecommunications?

Ramon Margalef, director of the Institute when Agustí arrived, suggested he should build a device for counting plankton (Julià, 1969). This was a first step in incorporating electronics into ocean observation. At this time Antoni Ballester came to the Insti- tute after an initial experience with AutoAnalyzers in collaboration with the Royal Institute of Brussels, and Agustí started to become fully dedicated to oceanographic instrumentation. Spanish oceanographers were beginning to participate in international campaigns and to discover the possibilities afforded by the new electronic measurement instruments. Here at the Institute, Agustí worked decisively to set up the continuous analysis of the physical and chemical parameters of surface seawater (Ballester et al., 1972), a practice that later became generalized in oceanographic studies. He also participated in the development - perhaps too early_of the Divergent, one of the first undulating sampling devices, almost twenty years before the Sea Soar and other sophisticated towed instruments that are now available. All of this took place just before the coming into service of the first major Spanish oceanographic vessel, the RV Cornide de Saavedra, in 1971.

In the 1970s, the need for new instruments for the new vessel and the new developments in electronics led the Institute to set up a working group devoted to oceanographic instrumentation. The group, formed by Agustí, Pep Martínez and Joan 
Comas, developed prototypes and tested all kinds of new instruments over a period of more than 15 years. During this period, almost everything at the Institute that contained a diode went through their hands. The laboratories and data gathering and processing had been taken over by electronic instruments such as current meters, profilers and fluorometers. Everyone used them. It was a difficult time and a lot of work needed to be done. Agustí was everywhere, trying not to ignore anyone or any problem, and providing support for many of the oceanographic sampling studies that were carried out. Miraculously, he even found time to train himself and to experiment with new technologies, such as the use of satellites for oceanic observation. In late 1986, he formed part of the pioneering team in Spanish Antarctic research. A group of four persons (A. Ballester, J. Castellví, A. Julià and J. Rovira) was invited by the Polish Academy of Sciences to take part in the Antarctic campaign that established the position of the Spanish Antarctic Base on Livingstone Island, thus opening the door to the Spanish candidature as a consultative member of the Antarctic Treaty. Curiously, this achievement brought, Agustí, a staunch republican, to be one of the few members of the Institute who has received the personal recognition of the King of Spain.

These events marked a great step forward for oceanography in Spain. The Institute's instrumental capacity increased by almost one order of magnitude, and a Marine Technology Unit was created to meet the instrumental equipment requirements of oceanographic vessels and the Antarctic base. Nevertheless, Agustí continued his instrumentation work, day by day, with current meters, moorings and buoys. Maribel Lloret now joined the team. Agustî́s keen dedication continued unchanged after his official retirement age, until he fell ill in 2008, just when he was enthusiastically preparing for a new Antarctic campaign, in which unfortunately he was unable to participate.
His great knowledge of the sea and the behaviour of instruments in the marine environment and, in particular, his willingness to collaborate with everyone, led Agustí to work with teams from many national and international institutions almost right from the start of his career. He worked with almost all the institutions working in oceanography in Spain: other centres belonging to the Spanish National Research Council (CSIC), the Spanish Oceanographic Institute (IEO), Puertos del Estado and many universities, including in particular the Marine Engineering Laboratory of the Universitat Politècnica de Catalunya. He also collaborated with the French National Centre for Scientific Research (CNRS), with IFREMER, with French universities, with the Italian National Research Council (CNR) and with several research groups in American universities.

Agustí's death has left a great void for the hundreds of people from many places who shared work and leisure time with him, both on land and at sea. At his side it was almost impossible to become disillusioned. However difficult the conditions were (and they were often extreme), with Agustí everything seemed feasible and much easier. "No problem!", he used to say with a smile, "Let's get down to it!". He was so optimistic that just before his death he still managed to convince us that he would soon be back at work. Unfortunately, this was not the case, and we are very sad that he is no longer with us.

\section{REFERENCES}

Ballester, A., A. Cruzado, A. Julià, M. Manríquez, J. Salat. - 1972. Análisis automático y continuo de las características físicas, químicas y biológicas del mar. Publ. Téc. Patronato Juan de la Cierva C.S.I.C., 1: 1-68.

Julià, A. - 1969. Contador óptico de partículas en suspensión de tamaño mediano y grande (micro y meso-plancton). Inv. Pesq., 33(1): 201-211.

JORDI SALAT Institut de Ciències del Mar (CMIMA-CSIC) 

In January 2006 the Consejo Superior de Investigaciones Cientificas (CSIC) became a signatory to the Berlin Declaration on Open Access to Knowledge in the Sciences and the Humanities. The CSIC has implemented this commitment through the development of a CSIC Journals Platform, which has been accessible since 7 September 2007 at:

\section{http://revistas.csic.es}

The CSIC Journals Platform is a project carried out jointly by the Publications Department of the CSIC and the Centre for Scientific Information and Documentation (CINDOC), in collaboration with the editorial staff of each journal. This initiative is the continuation of the programme of modernisation and standardisation of the periodical publications of the CSIC that has been underway since 2004 .

The content of the latest volumes of the journal Scientia Marina can be obtained through this platform:

\section{http://scientiamarina.revistas.csic.es}

Furthermore, all the volumes of the journal Scientia Marina, and its predecessor Investigación Pesquera, can be accessed in electronic format through the web page of the Journal:

\section{http://www.icm.csic.es/scimar/}

The content of the electronic version is identical to that of the print version and the full text is accessible without restrictions. The Journal also provides access to the articles when the galley proofs have been accepted by the authors and the editor.

En enero de 2006 el Consejo Superior de Investigaciones Científicas (CSIC) se adhirió a la Declaración de Berlín sobre el acceso abierto al conocimiento en Ciencias y Humanidades. El CSIC ha materializado dicho compromiso mediante el desarrollo de una Plataforma de Revistas del CSIC, accesible desde el 7 de septiembre de 2007 en la dirección:

\section{http://revistas.csic.es}

La Plataforma Revistas CSIC es un proyecto realizado conjuntamente por el Departamento de Publicaciones del CSIC y el Centro de Información y Documentación Científica (CINDOC), en colaboración con el Equipo Editorial de cada una de las revistas. Esta iniciativa es continuación del programa de modernización y homogeneización de las publicaciones periódicas del CSIC que se desarrolla desde 2004.

Los contenidos de los últimos volúmenes de la revista Scientia Marina pueden obtenerse desde dicha plataforma:

\section{http://scientiamarina.revistas.csic.es}

Asimismo, todos los volúmenes de la revista Scientia Marina, así como de su predecesora Investigación Pesquera están accesibles en versión electrónica a través de la página web de la revista:

\section{http://www.icm.csic.es/scimar/}

Los contenidos de la versión electrónica son idénticos a los de la versión impresa y accesibles a texto completo y sin restricciones. La revista permite también el acceso a los artículos una vez las pruebas de imprenta están aceptadas por los autores y el editor. 
